\title{
PENENTUAN SEKTOR UNGGULAN PEREKONOMIAN WILAYAH KABUPATEN BONE BOLANGO DENGAN PENDEKATAN SEKTOR PEMBENTUK PDRB
}

\author{
Fitri Amalia
}

Ikatan Sarjana Ekonomi Indonesia

\begin{abstract}
Economic Leading Sector Determination in Bone Bolango District Using GDRP-Forming Sector Approach. Economic growth and its process are the main condition for the sustainability of the regional economic development. Because of the continuing population growth means economic needs also increase so that additional revenue required each year. This research is focused to determine the regional leading sector of Bone Bolango as the information and considerations in planning economic development. Location Quotient (LQ) and Shift Share are tools of analysis. Location Quotient analysis indicates agriculture, manufacture, finance, leasing and corporate services are base sectors in the Bone Bolango district. Shift Share analysis indicates that the competitive sectors are finance, leasing and corporate services. The results was indicate that the leading sector with the criteria developed, base, and competitive is finance and services sector.
\end{abstract}

Keywords: location quotient (LQ), shift share analysis, growth, leading sector

\begin{abstract}
Abstrak. Penentuan Sektor Unggulan Perekonomian Wilayah Kabupaten Bone Bolango Dengan Pendekatan Sektor Pembentuk PDRB. Pertumbuhan ekonomi dan prosesnya merupakan kondisi utama untuk menjaga pembangunan ekonomi wilayah. Hal ini disebabkan pertumbuhan populasi membawa makna kebutuhan ekonomi yang turut pula membutuhkan tambahan pendapatan di tiap tahun. Fokus penelitian ini ialah kepada penentuan sektor unggulan ekonomi di Kabupaten Bone Bolangon sebagai pertimbangan dalam perencanaan pembangunan ekonomi. Analisis yang dipergunakan ialah Location quotient (LQ) dan shift share. Analisis LQ untuk mengindikasikan pertanian, manufaktur, keuangan, penyewaan dan jasa perusahaan sebagai sektor basis di Bone Bolango. Analisis shift share dipergunakan untuk mengindikasikan sector kompetitif pada keuangan, penyewaan, dan jasa perusahaan. Hasil yang didapat menunjukkan bahwa sektor keuangan dan jasa dapat menjadi sector ekonomi unggulan di Bone Bolango.
\end{abstract}

Kata Kunci: location quotient (LQ), analisis shift-share, pertumbuhan, sektor unggulan 


\section{PENDAHULUAN}

Pembangunan di negara-negara berkembang pada umumnya termasuk di Indonesia masih memunculkan adanya dualisme yang mengakibatkan adanya gap atau kesenjangan antara daerah yang satu dengan daerah lainnya, antara kota dan desa, antara Pulau Jawa dengan luar Pulau Jawa maupun antara dua kawasan pembangunan Indonesia yakni Kawasan Barat dengan Kawasan Timur Indonesia. Selama ini tujuan yang ingin dicapai dari suatu pembangunan ekonomi adalah untuk meningkatkan taraf hidup masyarakat yang biasa diukur dengan tinggi rendahnya pendapatan per kapita. Dengan demikian tujuan pembangunan ekonomi disamping untuk meningkatkan pendapatan nasional juga untuk meningkatkan produktivitas. Pada umumnya dapat dikatakan bahwa tingkat output pada suatu saat tertentu ditentukan oleh tersedianya atau digunakannya baik sumberdaya alam maupun sumber daya manusia, tingkat teknologi, keadaan pasar dan kerangka kehidupan ekonomi (sistem perekonomian) serta sikap dari output itu sendiri (Soeparmoko, 2002).

Namun sejak era reformasi tahun 1999 terjadi pergeseran paradigma dalam sistim penyelenggaraan pemerintahan dari pola sentralisasi menjadi pola desentralisasi atau disebut Otonomi daerah yang mengandung makna, beralihnya sebagian besar proses pengambilan keputusan dalam perencanaan, pelaksanaan dan evaluasi penyelenggaraan pemerintahan dari pusat ke daerah (Armida, 2000). Hal ini membawa implikasi mendasar terhadap keberadaan tugas, fungsi dan tanggung jawab pelaksanaan otonomi daerah yang antara lain di bidang ekonomi yang meliputi implikasi terhadap pertumbuhan ekonomi dan pemerataan antar daerah serta pencarian sumber-sumber pembiayaan untuk pembangunan dengan cara menggali potensi yang dimiliki oleh daerah. Oleh sebab itu pembangunan ekonomi daerah sangat ditentukan oleh kebijakan daerah itu sendiri dalam menentukan sektor-sektor yang diprioritaskan untuk pertumbuhan ekonomi di daerah tersebut .

Berdasarkan UU No. 22 tahun 1999 yang kemudian diganti dengan UU No. 32 tahun 2004 tentang Pemerintahan Daerah, pemerintah daerah mempunyai kewenangan yang lebih luas untuk mengatur dan mengelola berbagai urusan penyelenggaran pemerintah bagi kepentingan dan 
kesejahteraan masyarakat daerah yang bersangkutan. Sedangkan dalam hal pembiayaan dan keuangan daerah diatur dalam UU Nomor 25 Tahun 1999 yang kemudian diganti dengan UU No. 33 tahun 2004 tentang Perimbangan Keuangan Antara Pusat dan Daerah tidak hanya kesiapan aparat pemerintah saja, tetapi juga masyarakat untuk mendukung pelaksanaan Otonomi Daerah dengan pemanfaatan sumber-sumber daya secara optimal. Pembangunan daerah harus sesuai dengan kondisi potensi serta aspirasi masyarakat yang tumbuh dan berkembang. Apabila pelaksanaan prioritas pembangunan daerah kurang sesuai dengan potensi yang dimiliki oleh masing-masing daerah, maka pemanfaatan sumber daya yang ada akan menjadi kurang optimal. Keadaan tersebut dapat mengakibatkan lambatnya proses pertumbuhan ekonomi daerah yang bersangkutan.

Perencanaan pembangunan dapat dikatakan sangat identik dengan ekonomi pembangunan. Bila sekiranya ruang gerak ekonomi pembangunan berusaha mencari strategi pembangunan, perencanaan pembangunan merupakan alat yang ampuh untuk menerjemahkan strategi pembangunan tersebut dalam berbagai program kegiatan yang terkoordinir. Koordinasi ini perlu dilakukan sehingga sasaran-sasaran, baik ekonomi maupun sosial yang telah ditetapkan semula dapat dicapai secara lebih efisien. Dengan jalan demikian, akan dapat dihindari terjadinya pemborosan-pemborosan dalam pelaksanaan pembangunan.

Pengembangan metode untuk menganalisis suatu perekonomian suatu daerah penting sekali kegunaanya sebagai sarana mengumpulkan data tentang perekonomian daerah yang bersangkutan serta proses pertumbuhannya. Pengembangan metode analisis ini kemudian dapat dipakai sebagai pedoman untuk menentukan tindakan-tindakan apa yang harus diambil guna mempercepat laju pertumbuhan yang ada. Akan tetapi di pihak lain harus diakui, menganalisis perekonomian suatu daerah sangat sulit (Arsyad, 1999). Beberapa faktor yang sering menjadi penghambat dalam melakukan analisis perekonomian diantaranya: Data tentang daerah sangat terbatas terutama kalau daerah dibedakan berdasarkan pengertian daerah nodal (berdasarkan fungsinya). 
Sirojuzilam (2008) menyatakan bahwa pendekatan perencanaan regional dititikberatkan pada aspek lokasi di mana kegiatan dilakukan. Pemerintah daerah mempunyai kepentingan yang berbeda-beda dengan instansiinstansi di pusat dalam melihat aspek ruang di suatu daerah. Artinya bahwa dengan adanya perbedaan pertumbuhan dan disparitas antar wilayah, maka pendekatan perencanaan parsial adalah sangat penting untuk diperhatikan. Dalam perencanaan pembangunan daerah perlu diupayakan pilihan-pilihan alternatif pendekatan perencanaan, sehingga potensi sumber daya yang ada akan dapat dioptimalkan pemanfaatannya. Kebijakan pembangunan wilayah merupakan keputusan atau tindakan oleh pejabat pemerintah berwenang atau pengambil keputusan publik guna mewujudkan suatu kondisi pembangunan. Sasaran akhir dari kebijakan pembangunan tersebut adalah untuk dapat mendorong dan meningkatkan pertumbuhan ekonomi dan kesejahteraan sosial secara menyeluruh sesuai dengan keinginan dan aspirasi yang berkembang dalam masyarakat.

Pengembangan wilayah diartikan sebagai semua upaya yang dilakukan untuk menciptakan pertumbuhan wilayah yang ditandai dengan pemerataan pembangunan dalam semua sektor dan pada seluruh bagian wilayah. Pertumbuhan ekonomi dapat terjadi secara serentak pada semua tempat dan semua sektor perekonomian, tetapi hanya pada titik-titik tertentu dan pada sektor-sektor tertentu pula. Wilayah yang memiliki potensi berkembang lebih besar akan berkembang lebih pesat, kemudian pengembangan wilayah tersebut akan merangsang wilayah sekitarnya. Bagi sektor yang memiliki potensi berkembang lebih besar cenderung dikembangkan lebih awal yang kemudian diikuti oleh perkembangan sektor lain yang kurang potensial.

Beberapa hasil penelitian dan studi empiris mengenai analisis potensi daerah telah banyak dilakukan oleh beberapa peneliti. Alat analisis yang dapat digunakan diantaranya analisis Location Quotient (LQ), analisis shift-share maupun tipologi Klassen. Penelitian yang dilakukan oleh Marhayanie (2003), menunjukkan kontribusi per sektor, analisis linkage, analisis angka pengganda diperoleh bahwa sektor ekonomi yang potensial dalam perencanaan pembangunan Kota Medan adalah sektor industri pengolahan. Hasil penelitian 
yang diperoleh Supangkat (2002) menunjukkan bahwa sektor pertanian dan industri pengolahan berpeluang untuk dijadikan sebagai sektor prioritas bagi peningkatan pembangunan di daerah Kabupaten Asahan, terutama sub sektor perkebunan, perikanan dan industri besar, serta sedang. Penelitian Tampubolon (2001), dengan judul Pembangunan dan Ketimpangan Wilayah Pantai Barat dan Pantai Timur Sumatera Utara, menyimpulkan bahwa karakteristik wilayah mempengaruhi ketimpangan pendapatan antar wilayah. Potensi sektor-sektor wilayah mempengaruhi perubahan struktur ekonomi. Struktur ekonomi wilayah pantai barat menuju industri pengolahan hasil pertanian dan struktur ekonomi wilayah pantai timur menuju industri pengolahan barang jadi.

Kabupaten Bone Bolango merupakan salah satu kabupaten di Propinsi Gorontalo yang terbentuk pada tahun 2003. Sementara Gorontalo sendiri sebagai salah satu propinsi di Indonesia yang ke-32, dimana sebelumnya Gorontalo merupakan wilayah Kabupaten Gorontalo dan Kota Madya Gorontalo di Sulawesi Utara. Namun seiring dengan munculnya pemekaran wilayah berkenaan dengan otonomi daerah, propinsi ini kemudian terbentuk pada Desember 2000. Kabupaten ini memiliki 17 kecamatan, 4 kelurahan dan 152 desa. Jika dibandingkan dengan kabupaten/kota lainnya di Propinsi Gorontalo, Kabupaten Bone Bolango memiliki laju pertumbuhan ekonomi terendah (6,66\%) dan tingkat pengangguran terbuka tertinggi, yakni 8,28\% (BPS Bone Bolango, 2010). Sehingga masih perlu penanganan lebih intensif dalam hal penciptaan lapangan pekerjaan dan lapangan usaha agar dapat meningkatkan perekonomian masyarakat.

Perkembangan Kabupaten Bone Bolango setiap tahun mengalami pertambahan penduduk seiring dengan perkembangan pembangunan masyarakat, baik pembangunan dalam bidang pendidikan maupun bidang pembangunan lainnya seperti pada sektor pembangunan ekonomi dan perkembangan kemasayarakatan yang mendorong banyaknya muncul aspek kehidupan masyarakat yang mendrong timbulnya pola kehidupan masyarakat yang mengutamakan tuntutan pemenuhan kebutuhan ekonominya.

Sasaran pembangunan bidang ekonomi adalah pertumbuhan ekonomi yang cukup tinggi. Secara agregat, pertumbuhan ekonomi Kabupaten Bone 
Bolango pada tahun 2006 mencapai 5,28 \%. Seluruh sektor ekonomi pada tahun 2006 menunjukkan pertumbuhan positif, namun pertumbuhan tertinggi dialami oleh sektor Listrik, Gas dan air bersih yang meningkat sebesar 8,19 \% dan diikuti oleh sektor Pengangkutan dan Komunikasi yang pertumbuhannya mencapai 8,18 \% sedangkan sektor pertanian tumbuh sebesar 7,84 \%.

Pada distribusi persentase PDRB Kabupaten Bone Bolango Tahun 2004 2006 atas dasar harga berlaku menunjukkan sektor pertanian memberikan peranan terbesar yakni 37,16 \% untuk tahun 2004, 39,39\% untuk tahun 2005 dan 41,38\% untuk tahun 2006. Hal ini mengindikasikan bahwa peranan sektor pertanian sangat besar terhadap struktur ekonomi Kabupaten Bone Bolango. Pertumbuhan sektor pertanian pada tahun 2006 sebesar 7,84 \% menunjukkan suatu peningkatan yang pesat, mengingat pertumbuhan sektor ini pada tahun 2005 hanya mencapai 5,05 \%. Sub sektor yang mengalami pertumbuhan tertinggi adalah sub sektor peternakan sebesar 26,24 \%. Diikuti oleh sub sektor tanaman bahan makanan, perikanan dan tanaman perkebunan masing - masing sebesar 7,49 \%, 2,78 \% dan 2,50 \%. (Bappeda.gorontalokab.go.id)

Berdasarkan latar belakang diatas, maka untuk memecahkan masalah di atas perlu adanya usaha peningkatan kemampuan dibidang ekonomi di Kabupaten Bone Bolango melalui analisis pertumbuhan ekonomi (PDRB) dengan pendekatan basis ekonomi, Pendekatan basis ekonomi ini ditujukan untuk mengidentifikasi sektor-sektor mana yang paling unggul dan strategis untuk dikembangkan. Tujuan penelitian ini adalah untuk mengetahui sektorsektor apakah yang menjadi sektor basis dan non basis dalam perekonomian Kabupaten Bone Bolango serta bagaimanakah perubahan dan pergeseran sektor perekonomian Kabupaten Bone Bolango.

\section{METODE}

Menurut Suharsimi (1998), populasi merupakan keseluruhan subyek penelitian. Yang menjadi populasi dalam penelitian ini adalah PDRB sektoral Kabupaten Bone Bolango dan Propinsi Gorontalo yang dihitung berdasarkan harga konstan tahun 2000. Data yang digunakan dalam penelitian ini merupakan data sekunder. Untuk menjawab permasalahan yang telah ditetapkan, maka digunakan beberapa metode analisis data, yaitu: Analisis 
Location Quotient (LQ) digunakan untuk menentukan sektor basis dan non basis dalam perekonomian Kabupaten Bone Bolango, serta Analisis Shift Share digunakan untuk mengetahui perubahan dan pergeseran sektor perekonomian Kabupaten Bone Bolango.

\section{Analisis Location Quotient}

Teknik Analisis Location Quotient ini memiliki asumsi bahwa semua penduduk di suatu daerah mempunyai pola permintaan yang sama dengan pola permintaan nasional (regional). Bahwa produktivitas tiap pekerja di setiap sector industri di daerah adalah sama dengan produktivitas pekerja dalam industri nasional. Setiap industri menghasilkan barang yang homogen pada setiap sektor, dan bahwa perekonomian bangsa yang bersangkutan adalah suatu perekonomian tertutup. Apabila hasil perhitungannya menunjukkan LQ > 1, berarti merupakan sektor basis dan berpotensi untuk ekspor, sedangkan LQ < 1, berarti bukan sektor basis (sektor lokal/impor).

\section{Analisis Shift Share}

Analisis Shift Share ini digunakan untuk menentukan kinerja atau produktivitas suatu daerah, pergeseran struktur, posisi relatif sektor-sektor ekonomi dan identifikasi sektor-sektor ekonomi potensial suatu daerah kemudian membandingkannya dengan daerah yang lebih besar (regional/nasional). Analisis ini memberikan data tentang kinerja perekonomian dalam 3 bidang yang berhubungan satu sama lain (Arsyad 1999). Tiga bidang yang saling berhubungan itu meliputi: Pertama, pertumbuhan ekonomi daerah diukur dengan cara menganalisis perubahan pengerjaan agregat secara sektoral kemudian dibuat perbandingan dengan sektor perekonomian yang sama sebagai acuan, sehingga diketahui perubahanperubahan dan perbandingannya.

Kedua, Pergeseran proporsional (proportional shift) digunakan untuk mengukur perubahan relatif, pertumbuhan atau penurunan, pada daerah dibandingkan dengan perekonomian yang lebih besar yang dijadikan acuan. Pengukuran ini memungkinkan kita untuk mengetahui apakah perekonomian daerah terkonsentrasi pada industri-industri yang tumbuh lebih cepat ketimbang perekonomian yang dijadikan acuan. Ketiga, Pergeseran diferensial 
(differential shift) digunakan untuk membantu dalam menentukan seberapa jauh daya saing industri daerah (lokal) dengan perekonomian yang dijadikan acuan. Oleh karena itu jika pergeseran diferensial dari satu industri adalah positif, maka industri tersebut lebih tinggi daya saingnya dibanding industri yang sama pada perekonomian yang dijadikan acuan.

Glasson (1990) merumuskan analisis shift share adalah sebagai berikut:

$\begin{array}{ll}\text { Gj } & : Y j t-Y j o \\ & :(N j+P j+D j) \\ \text { Nj } & : Y j o(Y t / Y o)-Y j o \\ (P+D) j & : Y j t-(Y t / Y o) Y j o \\ & :(G j-N j) \\ P j & : \Sigma i[(Y i t / Y i o)-(Y t / \text { Yo })] \text { Yijo } \\ \text { Dj } & : \Sigma t[Y i j t-(Y i t / \text { Yio) Yijo] } \\ & :(P+D) j-P j\end{array}$

Dimana Gj adalah Pertumbuhan PDRB Total Kabupaten Bone Bolango, Nj adalah Komponen Share di Kabupaten Bone Bolango, (P + D)j adalah Komponen Net Shift di Kabupaten Bone Bolango, Pj adalah Proportional Shift Kabupaten Bone Bolango, Dj adalah Diferential Shift Kabupaten Bone Bolango, Yj adalah PDRB total Kabupaten Bone Bolango, Y adalah PDRB Total Propinsi Gorontalo, o dan $\mathrm{t}$ adalah Periode Awal dan Periode Akhir Perhitungan, i adalah Subskripsi Sektor (subsektor) pada PDRB.

Jika $\mathrm{Dj}>0$, maka pertumbuhan sektor i di Kabupaten Bone Bolango lebih cepat dari pertumbuhan sektor yang sama di Propinsi Gorontalo dan bila $\mathrm{Dj}<0$, berarti pertumbuhan sektor i di Kabupaten Bone Bolango relatif lebih lambat dari pertumbuhan sektor yang sama di Propinsi Gorontalo. Bila Pj > 0, maka Kabupaten Bone Bolango akan berspesialisasi pada sektor yang di tingkat propinsi tumbuh lebih cepat. Sebaliknya jika $\mathrm{Pj}<0$, maka Kabupaten Bone Bolango akan berspesialisasi pada sektor yang di tingkat propinsi tumbuh lebih lambat.

\section{PEMBAHASAN}

Berdasarkan hasil, maka dapat diidentifikasikan sektor-sektor mana saja yang terdapat di Kabupaten Bone Bolango yang merupakan sektor basis maupun non basis. Kabupaten Bone Bolango selama 5 tahun terakhir ini secara rata-rata hanya mempunyai 3 sektor basis. Ketiga sektor basis tersebut adalah 
Sektor Pertanian, Sektor Industri Pengolahan dan Sektor Keuangan, Persewaan, Jasa Perusahaan. Sektor-sektor tersebut memiliki nilai indeks $L Q$ lebih dari 1.

Hasil indeks tersebut menunjukkan bahwa sektor-sektor tersebut memiliki kekuatan ekonomi yang cukup baik dan sangat berpengaruh terhadap peningkatan pertumbuhan ekonomi Kabupaten Bone Bolango dan sektor-sektor tersebut sudah mampu untuk memenuhi kebutuhan di daerahnya bahkan berpotensi untuk ekspor. Jika kita jabarkan secara terperinci dan diurutkan berdasarkan indeks terbesar, maka sektor Industri pengolahan merupakan sektor basis yang memiliki indeks terbesar dibandingkan dengan sektor basis lainnya yaitu dengan rata-rata sebesar 1,395, diikuti sektor Pertanian dengan indeks 1,122 dan sektor basis yang ketiga adalah sektor keuangan, persewaan dan jasa perusahaan dengan indeks 1,001. Ketiga sektor tersebut merupakan sektor basis yang merupakan modal yang cukup baik bagi perkembangan Kabupaten Bone Bolango.

Sektor yang merupakan sektor bukan basis selama periode tersebut adalah sektor Pertambangan, Penggalian, sektor Listrik, Gas, Air Bersih, sektor Bangunan, sektor Perdagangan, Hotel, Restoran, sektor Pengangkutan, komunikasi serta sektor Jasa-jasa lain. Keenam sektor bukan basis tersebut memiliki indeks LQ $<1$ dengan rata-rata indeks masing-masing 0.451, 0.543, $0.499,0.759,0.324$ dan 0.575. Sektor-sektor tersebut dalam berproduksi belum mampu memenuhi kebutuhan dalam Kabupaten Bone Bolango bahkan meingimpor dari luar daerah. Sektor bukan basis ini perlu mendapat perhatian khusus bagi para pengambil kebijakan di Kabupaten Bone Bolango. Dengan bermodalkan tiga sektor basis, diharapkan keenam sektor bukan basis dapat dibantu untuk dikembangkan menjadi sektor basis baru.

Analisis penentuan sektor ekonomi strategis dan memiliki keunggulan untuk dikembangkan dengan tujuan untuk memacu laju pertumbuhan Kabupaten Bone Bolango. Untuk mengetahui sektor spesialisasi daerah serta pertumbuhannya digunakan komponen Provincial Share, Proportional Shift, dan Differential Shift. Hasil perhitungan analisis shift share PDRB Kabupaten Bone Bolango tahun 2006-2010 dapat dilihat pada tabel 3. Nilai Differential Shift sektor perekonomian Kabupaten Bone Bolango selama periode tahun 2006- 
2010 ada yang positif dan negatif. Nilai Differential Shift positif, berarti bahwa terdapat sektor ekonomi Kabupaten Bone Bolango tumbuh lebih cepat dibandingkan sektor yang sama di tingkat Provinsi Gorontalo. Sedangkan nilai Differential Shift negatif, berarti sektor tersebut tumbuh lebih lambat dibandingkan sektor yang sama di tingkat Provinsi Gorontalo. Hanya terdapat satu sektor dalam perekonomian Kabupaten Bone Bolango dengan nilai Differential Shift negatif, yaitu: sektor bangunan dengan nilai Differential Shift sebesar -112,344, yang berarti sektor bangunan ini memiliki pertumbuhan yang lambat. Sedangkan delapan sektor lainnya memiliki nilai Differential Shift positif. Artinya pertumbuhan delapan sektor tersebut di kabupaten Bone Bolango lebih cepat dibandingkan pertumbuhan sektor yang sama di Propinsi Gorontalo. Delapan sektor tersebut memiliki potensi untuk dikembangkan dalam memacu pertumbuhan PDRB Kabupaten Bone Bolango. Kedua komponen shift ini memisahkan unsur-unsur pertumbuhan Kabupaten Bone Bolango yang bersifat intern dan ekstern, di mana proportional shift dari pengaruh unsurunsur luar yang bekerja dalam Provinsi Gorontalo dan differential shift adalah akibat dari pengaruh faktor-faktor yang bekerja di dalam Kabupaten Bone Bolango.

\section{SIMPULAN}

Sektor Industri pengolahan merupakan sektor basis yang memiliki indeks terbesar dibandingkan dengan dua sektor basis lainnya yaitu sektor Pertanian dan sektor keuangan, persewaan dan jasa perusahaan. Ketiga sektor basis ini merupakan modal yang cukup baik bagi perkembangan Kabupaten Bone Bolango. Hasil analisis shift share menunjukkan bahwa sektor yang merupakan sektor kompetitif, yaitu sektor keuangan, persewaan dan jasa perusahaan karena disamping merupakan sektor basis, sektor ini memiliki nilai shift yang positif.

Berdasarkan hasil pembahasan di atas, penulis menyarankan beberapa hal untuk pihak-pihak terkait, yaitu: pertama, Pemerintah Daerah Kabupaten Bone Bolango dalam upaya meningkatkan PDRB agar lebih mengutamakan pengembangan sektor dan sub sektor unggulan dengan tidak mengabaikan sektor dan sub sektor lain dalam perencanaan dan pelaksanaan pembangunan. 
Kedua, sektor keuangan, persewaan dan jasa perusahaan sebagai sektor unggulan dan memiliki kontribusi terbesar dalam perekonomian Kabupaten Bone Bolango perlu mendapatkan prioritas pengembangan, sehingga memberikan dampak yang tinggi bagi peningkatan pendapatan masyarakat dan lapangan pekerjaan. Ketiga, penelitian ini masih terbatas pada tahapan menentukan sektor dan sub sektor unggulan, kepada peneliti lainnya disarankan untuk melanjutkan penelitian ini sampai pada tahapan menentukan komoditi unggulan.

\section{PUSTAKA ACUAN}

Alisyahbana, A.S. 2000. Desentralisasi Fiskal dan Kebijakan Pembangunan Ekonomi Daerah: Makalah disampaikan pada kongres ISEI XIV, 21-23 April, di Makasar

Arsyad, L. 1999. Ekonomi Pembangunan. Yogyakarta: STIE YKPN.

Arsyad, L. 1999. Pengantar Perencanaan dan Pembangunan Ekonomi Daerah. Yogyakarta: BPFE Yogyakarta

Glasson, J. 1990. Pengantar Perencanaan Regional. Terjemahan Paul Sihotang. Jakarta: LPFEUI.

Marhayanie. 2003. Identifikasi Sektor Ekonomi Potensial dalam Perencanaan Pembangunan Kota Medan. (Tesis Tidak Dipublikasikan). Medan: Program Pascasarjana Universitas Sumatra Utara.

Sirojuzilam. 2008. Disparitas Ekonomi dan Perencanaan Regional, Ketimpangan Ekonomi Wilayah Barat dan Wilayah Timur Provinsi Sumatera Utara. Medan: Pustaka Bangsa Press

Sjafrizal. 2008. Ekonomi Regional, Teori dan Aplikasi. Cetakan Pertama. Padang: Baduose Media.

Soeparmoko. 2002. Ekonomi Publik Untuk Keuangan dan Pembangunan Daerah. Edisi pertama. Yogyakarta: Penerbit Andi.

Suharsimi. 1998. Prosedur Penelitian Suatu Pendekatan Praktek. Jakarta: Rineka Cipta.

Sihotang, H.S. 2002. Analisis Penentuan Sektor Prioritas dalam Peningkatan Pembangunan Daerah. (Tesis Tidak Dipublikasikan). Medan: Program Pascasarjana Universitas Sumatra Utara. 
Tampubolon, D. 2001. Pembangunan dan Ketimpangan Wilayah Pantai Barat dan Pantai Timur Sumatra Utara. (Tesis Tidak Dipublikasikan). Medan: Program Pascasarjana Universitas Sumatra Utara.

UU RI No. 32 Tahun 2004 dan UU RI No 33 Tahun 2004 Tentang Pemerintahan Daerah dan Tentang Perimbangan Keuangan Antara Pusat dan Daerah. Jakarta: CV Duta Nusindo.

Yunan, Z.Y. 2010. Sektor Basis dan Non Basis Di Kotamadya Tangerang Selatan (Suatu Pendekatan Location Quotient). Jurnal Signifikan: Vol 1. No. 2 Oktober 2010. 